\title{
DETECTION OF WOOD DECAY IN BLUE GUM AND ELM: AN EVALUATION OF THE RESISTOGRAPH ${ }^{\circledR}$ AND THE PORTABLE DRILL
}

\author{
by Laurence R. Costello' and Stephen L. Quarles ${ }^{2}$
}

\begin{abstract}
Decay and soundwood assessments made with the Resistograph ${ }^{\circledR}$ and the portable drill were compared with laboratory measurements of wood density. Sixteen Tasmanian blue gum (Eucalyptus globulus) and 5 Scotch elm (Ulmus glabra) were evaluated in the field, cut, sectioned along Resistograph and drill test paths, and measured for density. Resistograph measurements of soundwood depth agreed closely with density measurements in $85.5 \%$ of all cases for blue gum and $100 \%$ of all cases for elm. Portable drill measurements agreed closely with density measurements in $73 \%$ of cases for blue gum and $81 \%$ for elm. Drill evaluations varied considerably among operators. For both species, the Resistograph provided a higher level of consistency and reliability than the portable drill. For either method, familiarity with wood resistance patterns of the test species is critical for an accurate interpretation of decay presence or absence.
\end{abstract}

Key Words. Decay assessment; Resistograph; wood resistance; portable drill.

A measurement of internal decay is frequently needed when assessing hazard potential in urban trees. Instruments available to measure decay include penetrometers (Resistograph, Densitomat, and Sibert DDD 200), sonic and ultrasonic detectors (Metrigard Stress Wave Timer, Sound Impulse Hammer, and Arborsonic Decay Detector), electrical conductivity meter (Shigometer), increment borer, Fractometer, and the portable drill. Harris et al. (1999) described the use and limitations of many of these tools. Nicoletti and Miglietta (1998) reviewed technical features of several instruments and offered opinions on the reliability of each. Some of these tools have been evaluated for measuring wood decay in structures (Piirto and Wilcox 1978; Wilcox 1988; Zabel and Morrell 1992; Rinn 1993; Rinn et al. 1996).

This paper describes a field evaluation of two decay detection tools: the Resistograph ${ }^{\circledR}$ and the portable drill. The Resistograph is a relatively new instrument from Germany (Bethge et al. 1996). A battery-operated motor drives a specially engineered drill bit (referred to as a "needle" by the manufacturer) into the wood at a constant feed rate of 20,40 , or 60 $\mathrm{cm} / \mathrm{min}(8,16$, and $24 \mathrm{in} . / \mathrm{min})$. The drill bit is $30 \mathrm{~cm}$ (12 in.) long and has a diameter of $3 \mathrm{~mm}(0.12 \mathrm{in}$.) at the cutting tip and $1.5 \mathrm{~mm}(0.06 \mathrm{in})$ along the shaft. Changes in drilling resistance are plotted on a strip chart, and the pattern of resistance changes is used to determine decay presence or absence. Relatively high resistance readings indicate soundwood, while low readings suggest decay or other defects (Mattheck et al. 1997).

The portable drill has been used for a number of years by tree care professionals and is considered by many to be a reliable decay detection method (McNiel, pers. comm.). The portable drill functions in a fashion similar to the Resistograph, but the drill operator senses changes in wood resistance rather than the motor and gearbox of the Resistograph. A brad-point drill bit is driven into the tree, and changes in drill torque indicate changes in wood resistance. Drill bit length is $30 \mathrm{~cm}$ (12 in.) and diameter is $3.2 \mathrm{~mm}(0.13 \mathrm{in}$.). The operator notes wood resistance changes along the drill path and evaluates the condition of wood drillings (chips and shavings) removed from the hole. Based on both torque changes and wood evaluations, an assessment of decay presence or absence is made for each drilling location.

Both the Resistograph and the portable drill assess changes in the mechanical resistance of wood to quantify the amount of decay present. During the decay process, wood density decreases and, correspondingly, drilling resistance declines. This study evaluated the reliability of each instrument by comparing decay assessments generated from each instrument with decay assessments from laboratory measurements of wood density and visual examination of density samples. 


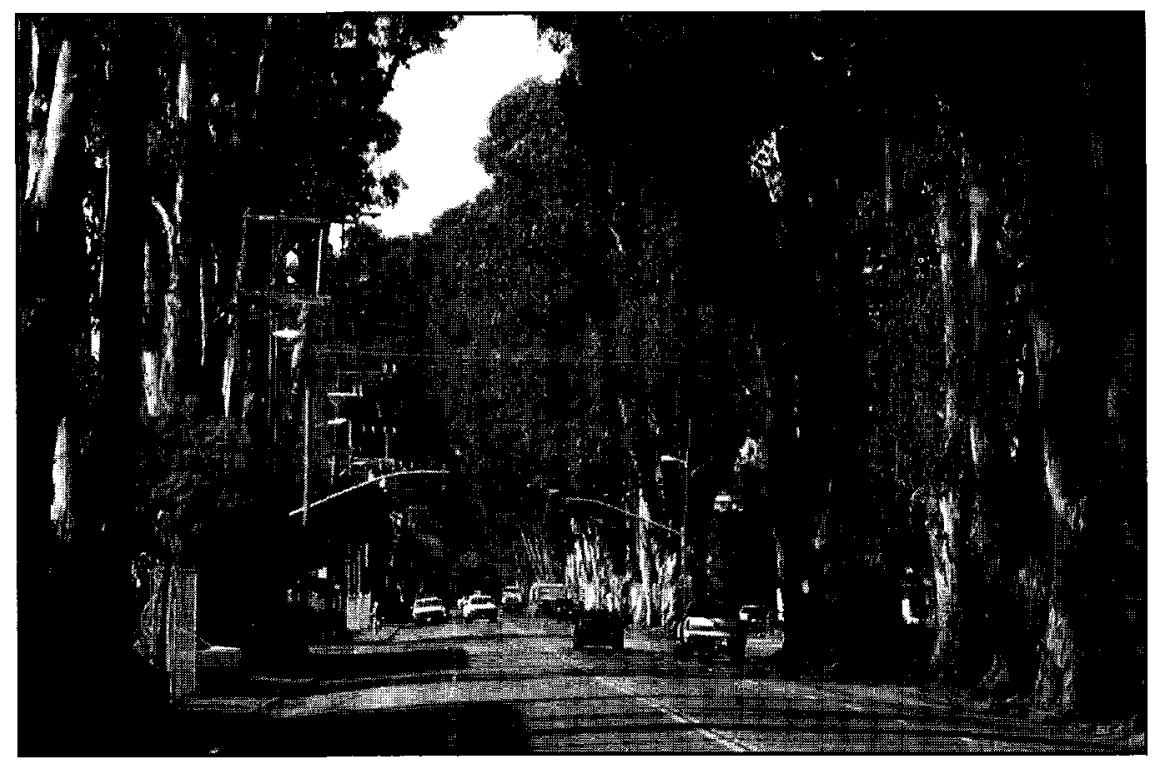

Figure 1. Sixteen Tasmanian blue gum (Eucalyptus globulus Labill.) and 5 Scotch elm (Ulmus glabra Huds.) were evaluated for decay in Burlingame, California. Trees were removed and sectioned following decay assessments. fungus, Laetiporus sulphureus.

Two Resistograph units (Model M300, IML, Inc., Marietta, GA) were used, while 4 operators were selected for portable drill evaluations, all using a DeWalt XR2 drill (Dewalt Industrial Tool Co., Hampstead, MD) with an $18-\mathrm{V}$ battery (Figure 2). Resistograph and drill measurements were made at the same relative locations on each of the test trees by using a template $(6 \times 11 \mathrm{~cm}[2.5 \times 4.5 \mathrm{in}]$. for each measurement site (Figure 3). Vertically aligned and evenly spaced on 1 side of the template were a Resistograph (R1) and 2 drill measurements (D1 and D2). At the same height,

\section{MATERIALS AND METHODS}

This study was initiated in 1997 in response to concerns regarding the hazard potential of very large blue gum (30 to $40 \mathrm{~m}$ tall [ 100 to $130 \mathrm{ft}$ ) and elm (15 to $20 \mathrm{~m}$ [50 to $65 \mathrm{ft}]$ ) trees on a major boulevard in Burlingame, California (Figure 1). In previous years, structural failures in these trees resulted in property damage and personal injury. The key defect associated with failure was decay.

Twenty-one trees were selected for decay evaluations: 16 blue gum (Eucalyptus globulus Labill.) and 5 Scotch elm (Ulmus glabra Huds.). Trees were mature (>75 years old) and showed signs of varying levels of decay caused by the brown rot

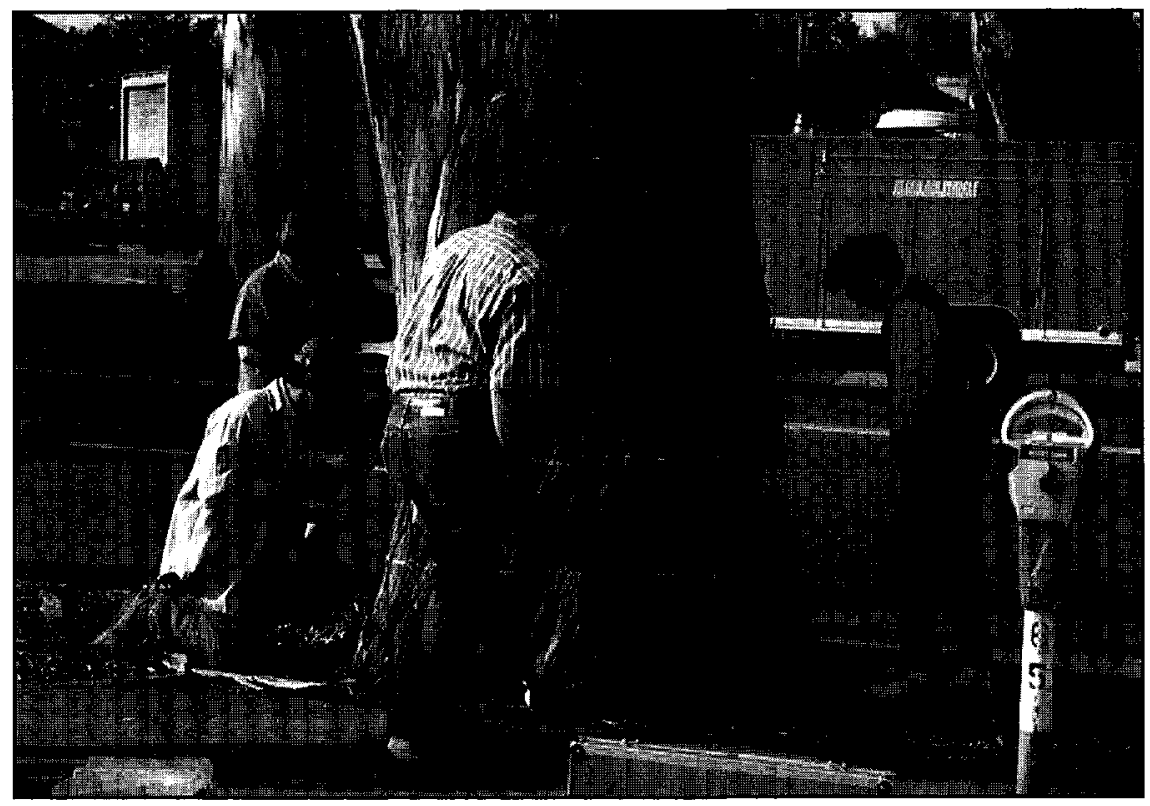

Figure 2. Wood decay being evaluated by research team members using the Resistograph (M300) and the portable drill. Four drill operators provided decay assessments at 3 sites on each tree, while 2 Resistograph units were used. 


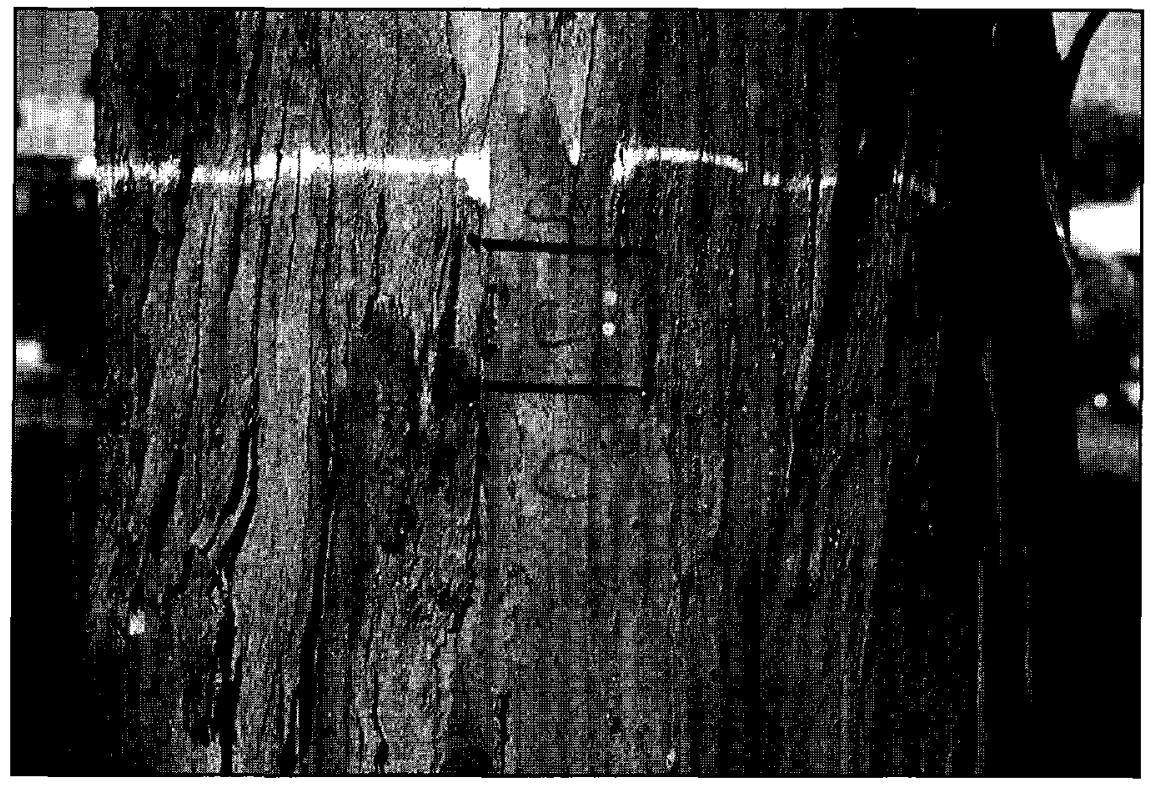

Figure 3. A template was used on all trees to consistently mark the location of Resistograph and drill measurements. Wood between measurement sites was sectioned and used for density analyses.

but $7.6 \mathrm{~cm}$ ( 3 in.) apart from these measurements, R2, D3, and D4 measurements were made in a parallel column. Three measurement sites were selected between 0.6 and $1.8 \mathrm{~m}$ ( 2 and $6 \mathrm{ft}$ ) aboveground on the trunk of each tree, for a total of 48 measurement sites on blue gum and 14 on elm. On 1 elm, only 2 template sites were accessible.

Fully charged Resistograph batteries were used at the beginning of each day. When battery charge was depleted, Resistograph measurements declined to zero and batteries were replaced. Resistograph operation was found to be adversely affected only when battery charge was fully depleted.

Drill evaluations were made every centimeter along drill paths using the following assessment categories: bark, soundwood, potential decay, decay, and cavity.

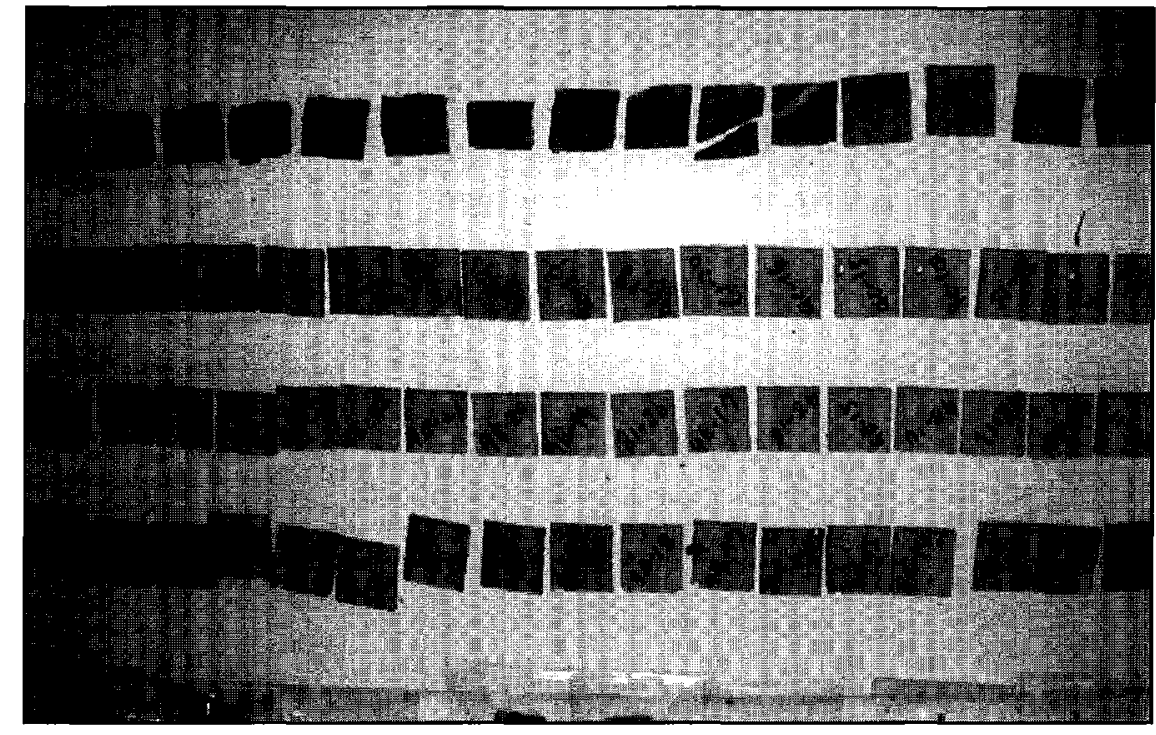

Figure 4. Wood sections between Resistograph and drill test sites were measured for density and arranged in sequence (as they occurred in the tree) for visual inspection.
These evaluations were transposed onto charts that were scaled the same as those used for Resistograph readings. Drill measurements were made independent of one another so readings made by 1 operator did not influence another.

After decay measurements were completed, trees were cut and trunk test sections ( $1 \mathrm{~m}[3.3 \mathrm{ft}]$ ) were wrapped in plastic and transported to the University of California Forest Products Laboratory in Richmond, California. Trunk sections were further sectioned to extract wood located between the 2 sets of Resistograph and drill measurements. Wood sections $(1 \times 1 \times 0.5 \mathrm{~cm}[0.4 \times 0.4 \times 0.2$ in. $])$ were removed along test paths (drill and Resistograph) and measured for density (Figure 4). Density values were plotted on charts equivalent to those used for Resistograph and drill measurements. 
Density values served as the experimental standard to assess soundness and decay in test sections. Because decay causes a loss of cell wall mass, a reduction in density can be used to identify decay levels. Soundwood density of blue gum was taken to be $0.65 \mathrm{~g} / \mathrm{cm}^{3}\left(40 \mathrm{lb} / \mathrm{ft}^{3}\right)$, while that of elm was $0.5 \mathrm{~g} /$ $\mathrm{cm}^{3}\left(31 \mathrm{lb} / \mathrm{ft}^{3}\right.$ ) (Kribs 1968). These values used for soundwood in eucalyptus and elm were supported by actual density measurements on the test trees. Density values greater than $0.5 \mathrm{~g} / \mathrm{cm}^{3}\left(31 \mathrm{lb} / \mathrm{ft}^{3}\right)$ in blue gum were considered to indicate soundwood, while those below $0.5 \mathrm{~g} / \mathrm{cm}^{3}$ indicated an intermediate or advanced level of decay. Elm wood densities greater than $0.4 \mathrm{~g} / \mathrm{cm}^{3}\left(25 \mathrm{lb} / \mathrm{ft}^{3}\right)$ were used to indicate soundwood, while those below $0.4 \mathrm{~g} / \mathrm{cm}^{3}$ indicated an intermediate to advanced level of decay. Positive readings for decay from density analyses were further supported by visual examination of wood samples.

Location of decay was identified on each of the Resistograph, drill, and density charts. Interpretation of decay for Resistograph charts was based on changes in drilling resistance along the drill bit path, as described by Mattheck et al. (1997). Drill charts showed specific locations where each operator believed decay was present. Density values below a critical level (see above) were used to determine decay location from wood samples. Using decay location evaluations, depth of soundwood was determined.

\section{RESULTS}

Depth of soundwood, or the amount of undecayed wood from inner bark to the point where decay is indicated (measured by linear distance), is of key interest when assessing structural strength loss resulting from decay (Mattheck and Briloer 1994). Soundwood depths indicated by drill and Resistograph measurements were compared with depth determined from laboratory density measurements. Differences between Resistograph and density measurements, and between drill and density measurements were grouped into 3 categories based on the magnitude of their deviation: 0 to $5 \mathrm{~cm}$ ( 0 to $2 \mathrm{in}$.), 6 to $10 \mathrm{~cm}(2.4$ to $4 \mathrm{in}$.), and 11 to $15 \mathrm{~cm}$ (4.3 to $5.9 \mathrm{in}$.). As an example, if density measurements indicated soundwood depth was $20 \mathrm{~cm}$ (7.9 in), and both detection methods found soundwood to be $20 \mathrm{~cm}$, then both evaluations would be entered in the 0 to $5 \mathrm{~cm}$ category.
Similarly, if one method found soundwood to be $9 \mathrm{~cm}$ ( $3.5 \mathrm{in}$.), and the other indicated $27 \mathrm{~cm}$ (10.6 in.), then the former evaluation would be entered in the 11 to $15 \mathrm{~cm}$ category, and the latter in the 6 to $10 \mathrm{~cm}$ category. Tables 1 and 2 report the number of cases found in each deviation group for each of the methods.

\section{Resistograph}

Averaging across all measurements for both units (Rl and R2), 85.5\% of Resistograph readings for blue gum were found to be in good agreement with density measurements ( 0 to $5 \mathrm{~cm}$ deviation group). All elm readings were in the 0 to $5 \mathrm{~cm}$ category (Table 1 ). Only $10.5 \%$ of blue gum readings deviated from density by 6 to $10 \mathrm{~cm}$, and $4 \%$ by 11 to 15 $\mathrm{cm}$. Little variation was found between Resistograph units. Resistograph results were highly correlated (0.975 to 0.993$)$ with density evaluations, and all were highly significant $(P<0.001)$ (Table 3 ).

Two Resistograph charts were not included in results analysis (Table 1) because interpretation of soundwood depth was equivocal. Wood resistance

Table 1. Soundwood depth evaluations for blue gum and elm using the Resistograph. The depth of soundwood using the Resistograph was compared to that value determined by wood density measurements. Resistograph deviations from density measurements were placed in 3 categories: 0 to 5 $\mathrm{cm}, 6$ to $10 \mathrm{~cm}$, and 11 to $15 \mathrm{~cm}$. Cases in the first category indicate very good agreement between the methods, while those in the second and third categories indicate lesser agreement. R1 = Resistograph $1, R 2$ = Resistograph 2 . Values indicate the number of cases in each deviation class and the percentage in each category.

\begin{tabular}{lrrrrr}
\hline Species & $\mathrm{R} 1$ & $\%$ & $\mathrm{R} 2$ & $\%$ & Mean (\%) \\
\hline Blue gum & & & & & \\
Deviation group & & & & & \\
0 to $5 \mathrm{~cm}$ & 38 & 85 & 41 & 86 & 85.5 \\
6 to $10 \mathrm{~cm}$ & 5 & 11 & 5 & 10 & 10.5 \\
11 to $15 \mathrm{~cm}$ & 2 & 4 & 2 & 4 & 4 \\
Total & $45^{*}$ & 100 & 48 & 100 & 100 \\
Elm & & & & & \\
Deviation group & & & & & \\
0 to $5 \mathrm{~cm}$ & 14 & 100 & 14 & 100 & 100 \\
\hline
\end{tabular}

Only 45 readings are reported for $\mathrm{R} 1$ because 2 charts were excluded (interpretation of Resistograph chart was equivocal) and 1 chart was lost. 
Table 2. Soundwood depth evaluations for blue gum and elm using the drill technique. The depth of soundwood using the drill was compared to that value determined by wood density measurements. Drill deviations from density measurements were placed in 3 categories: 0 to $5 \mathrm{~cm}, 6$ to 10 $\mathrm{cm}$, and 11 to $15 \mathrm{~cm}$. Cases in the first category indicate very good agreement between the methods, while those in the second and third categories indicate lesser agreement. D1 $=$ Drill $1, \mathrm{D} 2=$ Drill 2 , etc. Values in columns indicate the number of cases in each deviation class and the percentage in each category.

\begin{tabular}{lrrrrrrrrr}
\hline Species & D1 & $\%$ & D2 & $\%$ & D3 & $\%$ & D4 & $\%$ & Mean (\%) \\
\hline Blue gum & & & & & & & & & \\
Deviation group & & & & & & & & & \\
0 to $5 \mathrm{~cm}$ & 27 & 56 & 34 & 75 & 40 & 83 & 37 & 78 & 73 \\
6 to $10 \mathrm{~cm}$ & 8 & 17 & 6 & 13 & 5 & 11 & 4 & 8 & 12 \\
11 to $15 \mathrm{~cm}$ & 7 & 15 & 3 & 6 & 3 & 6 & 5 & 10 & 10 \\
$>15 \mathrm{~cm}$ & 6 & 12 & 3 & 6 & 0 & 0 & 2 & 4 & 5 \\
Total & 48 & & $46^{*}$ & & 48 & & 48 & & \\
Elm & & & & & & & & & \\
Deviation group & & & & & & & & & \\
0 to $5 \mathrm{~cm}$ & 10 & 72 & 11 & 79 & 12 & 86 & 12 & 86 & 81 \\
6 to $10 \mathrm{~cm}$ & 1 & 7 & 3 & 21 & 2 & 14 & 2 & 14 & 14 \\
11 to $15 \mathrm{~cm}$ & 1 & 7 & 0 & 0 & 0 & 0 & 0 & 0 & 2 \\
$>15 \mathrm{~cm}$ & 2 & 14 & 0 & 0 & 0 & 0 & 0 & 0 & 3 \\
Total & 14 & & 14 & & 14 & & 14 & & \\
\hline
\end{tabular}

"Only 46 readings are reported because 2 drill charts were excluded (readings were equivocal).

\section{Portable Drill}

Averaging across all measurements for all operators, $73 \%$ of drill assessments were in good agreement with density ( 0 to $5 \mathrm{~cm}$ deviation group) for blue gum, and $81 \%$ for elm (Table 2). Fifteen percent of measurements deviated from density values by more than 10 $\mathrm{cm}$ for blue gum, and $5 \%$ for elm. A considerable amount of variation was found among drill operators, ranging from $56 \%$ to $83 \%$ agreement for blue gum (0 to $5 \mathrm{~cm}$ deviation group) and $72 \%$ to $86 \%$ for elm. Operator D3 results were equivalent to those of the Resistograph, while operator D1 results showed the highest level of deviation. Operators D2 and D4 produced assessments that were berween those

patterns did not clearly delineate between decay and soundwood, and interpretations could be made for either decay or soundwood.

In cases of poor agreement between Resistograph and density measurements ( 11 to $15 \mathrm{~cm}$ deviation category), the Resistograph generated false negative assessments for decay: It indicated decay was not present when density readings were positive for decay. In most cases, this was found when density values were declining slowly from 0.65 to below $0.5 \mathrm{~g} / \mathrm{cm}$. Density readings indicated early to intermediate stages of decay, while drilling resistance did not change appreciably.

Density measurements indicated that sound wood only (no decay) was present in 5 blue gum. In each of these cases, Resistograph measurements were in full agreement with the density analysis.

In some blue gum, the path of the Resistograph drill bit crossed termite channels at various depths within the wood and low resistance readings resulted. Initially, these readings were interpreted as decay pockets. After subsequent visual inspection of wood sections, however, these interpretations were corrected and changed from decay to insect injury. of D3 and D1. Operators D1, D2, and D4 each reported soundwood depths in blue gum which differed from density assessments by more than $15 \mathrm{~cm}$ ( 6 in.), or over $50 \%$ of the $30 \mathrm{~cm}$ (12 in.) measurement path.

In three cases (D2, D3, and D4), drill evaluations were highly correlated with density evaluations $(0.887$ to 0.972$)$ and highly significant $(P<0.001)$. D1 evaluations were not significantly correlated with density for elm $(0.344, P>0.05)$ but were significant for blue gum

Table 3. Correlations between depth of soundwood as determined from laboratory density determinations and depth of soundwood determined by the Resistograph and portable drill.

\begin{tabular}{llc}
\hline & \multicolumn{2}{l}{ Correlation coefficient $(\mathrm{r})$} \\
\cline { 2 - 3 } Test & Elm & Blue gum \\
\hline Resistograph 1 & $0.993^{* * *}$ & $0.982^{* * *}$ \\
Resistograph 2 & $0.975^{* * *}$ & $0.977^{* * *}$ \\
Drill 1 & $0.344^{\text {ns }}$ & $0.729^{* * *}$ \\
Drill 2 & $0.913^{* * *}$ & $0.887^{* * *}$ \\
Drill 3 & $0.972^{* * *}$ & $0.930^{* * *}$ \\
Drill 4 & $0.926^{* * *}$ & $0.820^{* * *}$ \\
\hline
\end{tabular}

${ }^{n s}$ not significant.

${ }^{* * *} P<0.001$ 
$(0.729, P<0.001)$. Correlation coefficients for the portable drill were less than those found for the Resistograph.

In 5 trees where density evaluations determined the tree to be free of decay (soundwood only), operator D2 and D3 were in agreement for $93 \%$ of these cases, while D4 and D1 agreement was only $67 \%$ and $47 \%$, respectively.

\section{DISCUSSION}

Strong correlations found between laboratory density measurements and drilling resistance readings indicate that the Resistograph can produce reliable assessments of soundwood depth for both test species. Although the Resistograph did not detect early to intermediate stages of decay (less than a $20 \%$ weight loss, approximately), intermediate to advanced decay (greater than a $20 \%$ weight loss, approximately) was identified. Previously, Bethge et al. (1996) noted that the Resistograph cannot detect discolored wood or very early stages of decay. Schwarze (1999, pers. comm.) reported that the Resistograph detected brown rot at an earlier stage of decay than white or soft rot.

In cases where early to intermediate decay does not extend far (laterally) outside the cylinder of advanced decay, an evaluation of advanced decay alone should provide a reliable assessment of trunk or root cross-sectional area affected. In cases where early to intermediate decay advances well in front of an advanced decay cylinder, then the Resistograph may produce an assessment which underestimates the amount of decay present. An understanding of decay rate and pattern caused by wood-inhabiting fungi in different species will be useful when assessing the potential for early decay to extend laterally in front of columns of advanced decay (Schwarze et al. 1997).

Although Resistograph and density analyses agreed in all cases for elm, deviations in soundwood depth assessments were found for blue gum. Approximately $15 \%$ of Resistograph assessments deviated from density assessments by more than $6 \mathrm{~cm}$. Although it was noted that the Resistograph produced false negative evaluations for decay in blue gum, reasons for variation among species are not clear, but may be related to differences in wood anatomy and grain patterns. Nonetheless, it is vital to understand that drilling resistance profiles for soundwood will differ among species. The soundwood profile needs to be determined for representatives of the test species before decay assessments are made. Indeed, both the soundwood profile and the profile variation for the species needs to be known. When this information is well established then drilling resistance deviations related to decay can be identified. Matheny et al. (1999) noted a similar requirement for the Fractometer.

Resistograph measurements may differ within species as well. Mattheck et al. (1999) reported that drilling resistance patterns in individual trees can vary with measurement location (height on trunk, and within and between root buttresses) and with the differential effects of environmental factors (light, water, nutrient availability, terrain) on wood development.

Soundwood depth determinations using the portable drill did not correlate as closely with density assessments as Resistograph determinations. Although 1 operator (D3) produced assessments comparable to the Resistograph, correlations for the other 3 operators were notably less, and particularly so for D1 ( 0.344 for elm and 0.729 for blue gum). Even though most of these correlations were found to be highly significant, a correlation coefficient ( $r$ ) of 0.900 is suggested as the minimum needed to identify a strong correlation when comparing instruments measuring decay at one location in the same tree.

Both lower correlation values and variation among operators suggest that portable drill assessments of soundwood depth may be less reliable than Resistograph assessments. However, because some drill values were comparable to Resistograph readings, operator skill will make a large difference in assessment reliability. Used by a skilled operator, the portable drill can produce an assessment of soundwood depth comparable to the Resistograph, but when used by an unskilled operator, an unreliable assessment is possible.

In either case, knowledge of the soundwood profile for the test species is a necessary starting point. As with the Resistograph, an operator will need to know the drilling resistance profile for soundwood (and the variation in resistance) for each species evaluated.

For both methods, it is important to understand that decay is not the only condition that will cause a change in drilling resistance. Aside from natural variations in wood density (earlywood, latewood, tension and compression wood), other factors such as internal 
cracks or splits, ring shakes, and insect activity can produce resistance changes. In this study, termite activity caused noticeable changes in drilling resistance.

\section{CONCLUSIONS}

Results indicate that both the Resistograph and the portable drill can be used to produce reliable assessments of soundwood depth in blue gum and elm. The Resistograph was found to provide a higher level of consistency and reliability than the portable drill, however.

Because both methods require an interpretation of drilling resistance measurements to determine the location and amount of decay, soundwood assessments are only as good as the interpretation provided by the operator. When using either method, familiarity with drilling resistance patterns for the test species is critical for an accurate interpretation of decay presence or absence.

\section{LITERATURE CITED}

Bethge, K., C. Mattheck, and E. Hunger. 1996. Equipment for detection and evaluation of decay in trees. Arboric. J. 20:13-37.

Harris, R.W., J.R. Clark, and N.P. Matheny. 1999. Arboriculture: Integrated Management of Landscape Trees, Shrubs, and Vines. Prentice-Hall, Englewood Cliffs, NJ. 687 pp.

Kribs, D.A. 1968. Commercial Foreign Woods on the American Market. Dover Publications, Inc., New York, NY. 241 pp.

Matheny, N.P., J.R. Clark, D. Attewell, K. Hillery, A.W. Graham, and G. Posner. 1999. Assessment of fracture moment and fracture angle in 25 tree species in the United States using the Fractometer. J. Arboric. 25 (1): 18-23

Mattheck, C.G., K.A. Bethge, G.R. Bruder, and R. Kappel. 1999. The Resistograph: Information for practical use. Arborist News 8(3):42-44.

Mattheck, C., and H. Briloer. 1994. The Body Language of Trees: A Handbook for Failure Analysis. HMSO Publications, London, England. $240 \mathrm{pp}$.

Mattheck, C., K. Bethge, and W. Albrecht. 1997. How to read the results of Resistograph M. Arboric. J. 21:331346.

Nicoletti, G. and P. Miglietta. 1998. Using high-technology instruments to assess defects in trees. J. Arboric. 24(6):297-302.

Piirto, D.D., and W.W. Wilcox. 1978. Critical evaluation of the pulsed-current resistance meter for detection of decay in wood. For. Prod. J. 20(1):52- 57
Rinn, F. 1993. Catalog of relative density profiles of trees, poles, and timber derived from Resistograph microdrillings. Proceedings of the 9th International Symposium on Nondestructive Testing of Wood. Sept. 22-24, 1993. Madison, WI.

Rinn, F., F.H. Schweingruber, and E. Schar. 1996. Resisitogaph and X-ray density charts of wood: Comparative evaluation of drill resistance profiles and $\mathrm{X}$-ray density charts of different wood species. Holzforschung 50(4):303-311.

Schwarze, FWM.R., D. Lonsdale, and S. Fink. 1997. An overview of wood degradation patterns and their implications for tree hazard assessment. Arboric. J. $21: 1-32$.

Wilcox, W.W. 1988. Detection of early stages of wood decay with ultrasonic pulse velocity. For. Prod. J. 38(5):68-73.

Zabel, R.A., and J.J. Morrell. 1992. Wood Microbiology: Decay and Its Prevention. Academic Press, New York, NY.

Acknowledgments. It was only through the efforts of a very knowledgeable and dedicated research team that this study was possible. The authors wish to acknowledge and sincerely thank every member of the team for their contributions: Carol Adams, Consulting Statistician, Boulder Creek, CA; Liheng Chen, Research Assistant, UC Forest Products Laboratory, Richmond, CA; Phil Evans, San Francisco State University, San Francisco, CA; Katherine Jones, UC Cooperative Extension, Half Moon Bay, CA; Nelda Matheny, HortScience, Inc., Pleasanton, CA; Joseph McNiel, Consulting Arborist, Pleasant Hill, CA; Stephen Porter, Burlingame Parks Dept., Burlingame, CA; Richard Quadri, Burlingame Parks Dept. (retired), Burlingame, CA; John Stepp, Califormia Dept. of Transportation, Woodside, CA; and Wayne Wilcox, Professor, UC Forest Products Laboratory, Richmond, CA. In addition, we thank Tim Richmond, Parks Superintendent, Burlingame, CA; and John Britton and Denice Britton, Britton Tree, St. Helena, CA; for additional field support. Finally and importantly, we thank the California Department of Transportation and the City of Burlingame for their generous support of this study.

${ }^{1 *}$ University of California Cooperative Extension
625 Miramontes St., Room 200
Half Moon Bay, CA 94019

${ }^{2}$ Forest Products Laboratory

University of California

Berkeley, CA

* Corresponding author 
Résumé. Des évaluations comparatives de bois carié versus de bois sain ont été effectuées entre le Resistograph ${ }^{\circledR}$ et une perceuse portative et des mesures de densité du bois en laboratoire. Seize eucalyptus de Tasmanie (Eucalyptus globulus) et cinq ormes glabres (Ulmus glabra) ont été évalués sur le terrain puis coupés et sectionnés le long des zones de test menés avec le Resistograph et la perceuse pour en mesurer la densité du bois. Les mesures de profondeur de bois sain avec le Resistograph étaient très fortement identiques à celles de densité dans $85,5 \%$ des cas pour l'eucalyptus et $100 \%$ des cas pour l'orme. Les mesures avec une perceuse portative étaient très fortement identiques à celles de densité dans $73 \%$ des cas pour l'eucalyptus et $81 \%$ des cas pour l'orme. Les évaluations effectuées avec la perceuse variaient considérablement entre les différents opérateurs. Pour les deux espèces, le Resistograph fournissait un plus haut degré de cohérence et de fiabilité que la perceuse portative. Pour chacune des méthodes, la connaissance des patrons de résistance du bois des différentes espèces testées s'est avérée critique pour une interprétation précise de la présence ou l'absence de carie.

Zusammenfassung. Untersuchungen von Fäulnis und gesundem $\mathrm{Holz}$ mit dem Resistographen und dem $\mathrm{Zu}-$ wachsbohrer wurden mit Untersuchungen der Holzdichte im Labor verglichen. 16 Eukalyptus und 5 Ulmen wurden im Feld untersucht, gefällt, entlang der Bohrlöcher aufgetrennt und anschließsend die Holzdichte gemessen. Die Resistograph-untersuchungen des gesunden Holzes stimmten zu $85 \%$ bei Eukalyptus und zu $100 \%$ bei Ulmen mit den Laboruntersuchungen überein. Die Untersuchungen mit dem Zuwachsbohrer stimmten zu $73 \%$ bei den Eukalyptus und $81 \%$ bei der Ulme mit den Laborwerten überein. Die Bohrmessungen variierten stark unter den einzelnen Probennehmern. Für beide Arten lieferte der Resistograph verläßlichere Werte als der Zueachsbohrer. Bei beiden Methoden ist eine Vertrautheit mit den Holzwiderstandseigenschaften der Testbäume für eine akurate Interpretation von Fäulnis oder nicht dringend erforderlich.

Resumen. Se hicieron comparaciones de estimaciones de la madera en descomposición y en buen estado, hechas con Resistógrafo ${ }^{\circledR}$ y taladro portátil, contra mediciones de la densidad de la madera hechas en laboratorio. Dieciséis eucaliptos (Eucalyptus globulus) y cinco olmos (Ulmus glabra) fueron evaluados en el campo, cortados, seccionados en los lugares de prueba del Resistógrafo y el taladro, y fue medida su densidad. Las mediciones de madera sana del Resistógrafo estuvieron estrechamente de acuerdo con las mediciones de densidad en $85 \%$ de todos los casos para eucalipto, y en el $100 \%$ de todos los casos para el olmo. Las mediciones con el taladro portátil estuvieron de acuerdo con las mediciones de densidad en $73 \%$ de los casos para eucalipto y $81 \%$ para olmo. Las evaluaciones con el taladro variaron considerablemente entre los operarios. Para las dos especies, el Resistógrafo dio un mayor nivel de consistencia y confianza que el taladro portátil. Para ningún método, la familiaridad con los patrones de resistencia de la madera en las especies probadas es confiable para una interpretación precisa de la ausencia o presencia de descomposición. 